\title{
Eukaryotic Translation Initiation Factor 2 Subunit 1
}

National Cancer Institute

\section{Source}

National Cancer Institute. Eukaryotic Translation Initiation Factor 2 Subunit 1. NCI

Thesaurus. Code C104189.

Eukaryotic translation initiation factor 2 subunit 1 (315 aa, $\sim 36 \mathrm{kDa}$ ) is encoded by the human EIF2S1 gene. This protein plays a role in the initiation of protein translation. 